\title{
PENGARUH SPIRITUALITAS TERHADAP ETOS KERJA PRESPEKTIF AL QURAN
}

\author{
Subhan \\ Universitas Pamulang \\ subhankamila@gmail.com
}

\begin{abstract}
Physical and instinctive needs are natural and neutral, can not in itself be said that one's needs are higher than the other. It is precisely the way in which people manage and satisfy those needs that can be given a praiseworthy or despicable title. In the view of Islam, if these needs are met with the actions carried out according to Islamic guidance, then it will be a commendable act. Conversely, if these needs are met with acts that violate the guidance of Islam then he becomes a disgraceful act. Spiritual intelligence associated with the problem of meaning, value, spiritual intelligence is able to guide humans to find meaning and can also guide people in reaching his ideals. Spiritual intelligence goes beyond the ability to intelligently think, feel, act and behave in situational contexts or given frameworks. Spiritual intelligence enables humans to be wise in reflecting on the situation to find themselves more meaningful so as to be able to transform something more precious. With the formation of spirituality culture in the workplace, it is expected to form employees who are happy, know and able to meet the purpose of life. Such employees generally have a balanced life between work and person, between duty and service. In general, they also have higher performance. The results of a large consulting firm, the application of a spiritual work environment increase productivity and reduce turn over. Other studies show that employees of high spiritual intelligence and supported by a work environment that is also spiritual, positively become more creative, have high job satisfaction, are able to work well in teams, and have a high commitment to the organization.
\end{abstract}

\section{Keywords : Guidance of Islam, Spirituality}

\section{PENDAHULUAN}

Etos kerja dalam arti luas menyangkut akan akhlak dalam pekerjaan. Untuk bisa menimbang bagaimana akhlak seseorang dalam bekerja sangat tergantung dari cara melihat arti kerja dalam kehidupan, cara bekerja dan hakikat bekerja. Dalam Islam, iman banyak dikaitkan dengan amal. Dengan kata lain, kerja yang merupakan bagian dari amal tak lepas dari kaitan iman seseorang. Idealnya, semakin tinggi iman itu maka semangat kerjanya juga tidak rendah. Ungkapan iman sendiri berkaitan tidak hanya dengan hal-hal spiritual tetapi juga program aksi.

Dalam kehidupan sehari-hari sebagai umat Islam selain diperintahkan untuk beribadah Allah memerintahkan untuk bekerja (berusaha). Di dalam Al-Qur'an dan 
Hadist sudah jelas tentang pekerjaan yang baik dan bagaimana kita memperoleh rezeki dengan cara yang diridhai Allah SWT. Hal ini sangat penting sekali dibahas, karena semua orang dunia ini pasti membutuhkan makanan, sandang maupun papan.

Disini pasti manusia berlomba-lomba atau memenuhi kebutuhannya tersebut dengan bekerja untuk mendapatkan yang diinginkan sehingga kita juga harus tahu, bahwa semua yang kita dapatkan semuanya dari Allah SWT dan itu semua hanya titipan Allah SWT semata.Sebagai umatnya diwajibkan mengembangkannya dengan baik dan hati-hati

Secara metodologis penelitian ini diperoleh melalui riset kepustakaan (library research), data data yang dihimpun terdiri atas ayat-ayat al quran dan bahan bahan tertulis yang telah di publikasi dalam bentuk buku, jurnal dan majalah maupun internet, yang memilki kaitan langsung dan tidak langsung dengan penelitian ini.

Penelitian ini bukan hanya akan menyajikan kajian yang bersifat diskriptif akan tetapi juga secara analisi agar kajian ini dapat memberikan gambaran yang utuh tentang pengaruh spiritual terhadap kinerja karyawan, dosen atau para professional dalam menjalakan tugas di tempat mereka bekerja.

\section{TELAAH LITERATUR DAN PENGEMBANGAN HIPOTESIS}

\section{Pengertian Spiritual Islam}

Secara etimologi kata "sprit" berasal dari kata Latin "spiritus", yang diantaranya berarti "roh, jiwa, sukma, kesadaran diri, wujud tak berbadan, nafas hidup, nyawa hidup.” Dalam perkembangan selanjutnya kata spirit diartikan secara lebih luas lagi. Para filosuf, mengonotasian "spirit" dengan (1) kekuatan yang menganimasi dan memberi energi pada cosmos, (2) kesadaran yang berkaitan dengan kemampuan, keinginan, dan intelegensi, (3) makhluk immaterial, (4) wujud ideal akal pikiran (intelektualitas, rasionalitas, moralitas, kesucian atau keilahian).

Sementara itu, Allama Mirsa Ali Al-Qadhi dikutip dalam bukunya Dr. H. M. Ruslan, MA mengatakan bahwa spiriritualitas adalah tahapan perjalanan batin seorang manusiauntuk mencari dunia yang lebih tinggi dengan bantuan riyadahat dan berbagai amalan pengekangan diri sehingga perhatiannya tidak berpaling dari Allah, semata-mata untuk mencapai puncak kebahagiaan abadi. 
Selain itu, dikutip pada buku yang sama, Sayyed Hosseein Nash salah seorang spiritualis Islam mendefinisikan spiritual sebagai sesuatu yang mengacu pada apa yang terkait dengan dunia ruh, dekat dengan Ilahi, mengandung kebatinan dan interioritas yang disamakan dengan yang hakiki.

Spiritualitas menurut Ibn 'Arabi adalah pengerahan segenap potensi rohaniyah dalam diri manusia yang harus tunduk pada ketentuan syar'i dalam melihat segala macam bentuk realitas baik dalam dunia empiris maupun dalam dunia kebatinan.

Mujib dan Mudakkir memberi pengertian tentang kecerdasan spiritual islam sebagai kecerdasan yang berhubungan kemampuan memenuhi kebutuhan ruh manusia, berupa ibadah agar ia dapat kembali kepada penciptanya dalam keadaan suci. Kecerdasan spritual merupakan kecerdasan qalbu yang berhubungan dengan kualitas batin seseorang.ia menjangkau nilai luhur yang belum terjangkau oleh akal. (Abdul Mujib dan Jusuf Mudzakir, 329-330)

Pada dasarnya karena qalb suci, ia selalu merindukan Tuhannya, karena itu ia berusaha untuk selalu menuju Tuhannya. Lebih jauh mengenai dinamika qalb tadi Agustian merumuskan lebih mendalam melalui perumusan kecerdasan spiritual yang berdasarkan kacamata islam dan bisa diterima secara nalar serta oleh ilmu pengetahuan.

\section{Penjelasan Al-Qur'an tentang spiritual}

Sebagaimana disebutkan bahwa ranah spiritual esensinya bukanlah materi atau jasadiah akan tetapi ia merupakan konsep metafisika yang pengkajiannya melalui pendalaman kejiwaan yang seringkali disandarkan pada wilayah agama. Islam sebagai salah satu agama yang diturunkan oleh Allah SWT juga tidak terlepas dari ajaran spiritual yang melambangkan kesalahan pribadi seorang muslim.

Dalam hal ini, Allah SWT menjelaskan dalam surat Asy-Syams ayat 7-10 sebagai berikut:

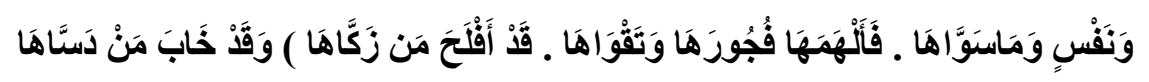

"Demi jiwa serta penyempurnaan (ciptaan)nya, maka Allah mengilhamkan kepada jiwa itu (perilaku) kejahatan dan ketakwaannya. Sungguh beruntung orang yang menyucikannya, dan sungguh merugi orang yang mengotorinya." (Qs. asySyams/91: 7-10).

Pada ayat di atas, setelah bersumpah dengan matahari, bulan, siang, malam, langit, dan bumi, Allah bersumpah atas nama jati diri/jiwa manusia dan 
penciptaannya yang sempurna. Lalu Allah mengilhamkan kefasikan dan ketakwaan ke dalam jiwa/diri manusia.

Al-Qurthubi mengatakan bahwa sebagian ulama mengartikan kata 'nafs' sebagai Nabi Adam, namun sebagian yang lain mengartikannya secara umum, yaitu jati diri manusia itu sendiri.

Menurut Ibn'Asyur, kata 'nafs' dalam ayat berbentuk nakirah (tanpa alif lam ta 'rif), ini menunjukkan nama jenis, sehingga mencakup jati diri seluruh manusia. Hal ini senada dengan penggunaan kata yang sama secara nakirah dalam ayat 5 surat al-Infithar:

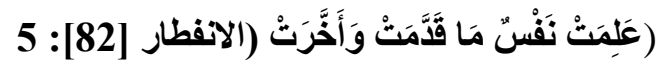

Maka tiap-tiap jiwa akan mengetahui apa yang telah dikerjakan dan yang dilalaikannya. (Q. S. al-Infithar [82]:8

Oleh karena itu kata 'wa ma sawwaha' mengandung penjelasan bahwa Allah menciptakan diri setiap manusia dalam kondisi yang sama, tidak berbeda antar satu dengan lainnya. Sebab kesempurnaan bentuk manusia (taswiyyah) tercapai setelah proses pembentukan janin sempurna, yaitu pada awal masa kanak-kanak.

Karena taswiyyah merupakan pembentukan fisik manusia, penyiapan kemampuan motorik, dan intelektual. Seiring pertumbuhannya, potensi dalam diri manusia meningkat sehingga ia siap menerima ilham dari Allah.

Kata ilham sebagaimana pengertian dalam ayat tidak dikenal di kalangan orang Arab sebelum Islam, sehingga penjelasan untuk kata ilham tidak bisa dicari dalam syair-syair Arab kuno. Tidak diketahui kapan pertama kali kata ini muncul, namun diyakini Alquran lah yang menghidupkan kata ini, sebab ia adalah kata yang mendalam dan mengandung makna kejiwaan. Menurut Ibn Asyur, kata ilham diambil dari kata "allahm" yang berarti tegukan dalam sekali gerak.

Secara terminologis, kata ilham digunakan untuk menyatakan konsep keilmuan tertentu di kalangan para ahli sufi. Ia diartikan sebagai hadirnya pengetahuan dalam diri manusia tanpa harus melalui usaha belajar dan penalaran. Dengan kata lain, ini merupakan ilmu yang tidak berdasar dalil, yaitu ilmu yang hadir seumpama insting bagi manusia. Bandingannya, seperti hadirnya pengetahuan pada seseorang agar segera menghindar saat berhadapan dengan hal yang tidak baik baginya.

Dengan pengertian seperti di atas, Ibn Abbas menafsirkan kata " $f a$ alhamaha fujuraha wa taqwaha," bahwa Allah mengajarkan manusia ('arrafaha) tentang jalan 
fasik, dan jalan takwa. Tidak jauh berbeda, Mujahid juga menafsirkan kataalhamaha sebagai 'arrafaha; bahwa Allah memperkenalkan jalan taat dan jalan maksiat bagi manusia. Penafsiran serupa juga dinyatakan oleh al-Farra', namun ada juga ulama yang melakukan penafsiran berbeda.

Tanpa pengilhaman kedua hal itu, akal tidak akan mampu memahami apa itu fasik dan takwa, demikian pula manusia tidak akan mampu memahami apa itu dosa dan pahala. Hal ini lah yang mempertautkan pernyataan ayat 8 dengan konsekuensinya dalam ayat 9 dan Redaksi dan munasabah menunjukkan bahwa kedua ayat ini merupakan kesatuan dengan ayat sebelumnya, jadi tidak bisa ditafsirkan secara terpenggal. Logika yang terbangun; setelah Allah menjelaskan adanya pengilhaman fujur dan taqwa dalam diri manusia, lalu Allah menyatakan konsekuensinya: "Sesungguhnya beruntunglah orang yang menyucikan jiwa itu, dan sesungguhnya merugilah orang yang mengotorinya. "Logika ini cukup relevan dengan redaksi ayat, sebab ayat 8 menggunakan waw'athaf yang berarti fujur dan taqwa sama-sama diilhamkan dalam jiwa manusia, maka pernyataan dalam ayat 9 dan 10 menunjukkan akibat dari fujur dan taqwa itu.

Dari itu manusia patut disifatkan sebagai orang yang beruntung atau rugi, karena ia sendiri yang memilih untuk menyucikan, atau mengotori jiwanya.

Sebab sebelumnya ia telah diberi ilham sehingga dapat membedakan antara fujur dan taqwa, bahkan para nabi pun telah diutus untuk memberinya pengajaran. Ayat-ayat diatas menyatakan bahwa dalam penciptaannya (jiwa) itu Allah telah mengilhamkan jalan kefasikan dan ketaqwaan kepadanya. Beruntunglah bagi orang yang mau menjaga dan membina untuk kesucian jiwanya dan rugilah orang yang tidak mau menjaga dan membina jiwanya, membiarkan dan mengotorinya. Jalan untuk menjaga dan membina jiwa banyak tantangan dan godaan, sedangkan jalan untuk mengotorinya mudah dan tanpa perjuangan.

Menjaga dan membina jiwa hanya dapat dengan tunduk kepada semua aturan Allah, beribadah kepada-Nya, selalu ingat dan bertaqarrub kepada-Nya, melaksanakan segala perintah-Nya dan menjauhi segala larangan-Nya. Dengan itulah jiwa terbina membentuk pribadi yang teguh memegang kebenaran dan keadilan untuk mencapai kesempurnaan hidup, kebahagiaan di dunia dan akhirat kelak, Insya Allah. Jiwa inilah yang akan mencapai ketenangan dan ketentraman dan jiwa inilah yang akan mendapatkan penghormatan yang tinggi dan agung 
mendapatkan panggilan yang penuh rindu dan kasih sayang-Nya. Seperti yang difirmankan Allah dalam QS.Al-Fajr: 27-30:

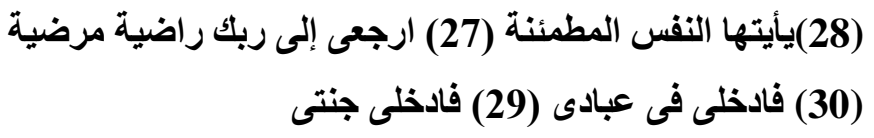

Wahai jiwa-jiwa yang tenang (27), kembalilah kepada Tuhanmu dengan rela dan diridlai (28), masuklah ke dalam golongan hamba-hamba-Ku (29), masuklah ke dalam sorga-Ku (30). [Q. S. al-Fajr, 89: 27-30].10

Jiwa inilah yang diseru oleh ayat ini: "Wahai jiwa yang telah mencapai ketentraman." (ayat 27). Yang telah menyerah penuh dan tawakkal kepada Tuhannya: Telah tenang, karena telah mencapai yakin: terhadap Tuhan.Berkata Ibnu 'Atha': "Yaitu jiwa yang telah mencapai ma'rifat sehingga tak sabar lagi bercerai dari Tuhannya walau sekejap mata." Tuhan itu senantiasa ada dalam ingatannya

Berkata Hasan Al-Bishri tentang muthmainnah ini: "Apabila Tuhan Allah berkehendak mengambil nyawa hamba-Nya yang beriman, tenteramlah jiwanya terhadap Allah, dan tenteram pula Allah terhadapnya."Berkata sahabat Rasulullah SAW 'Amr bin Al-'Ash (Hadis mauquf): "Apabila seorang hamba yang beriman akan meninggal, diutus Tuhan kepadanya dua orang malaikat, dan dikirim beserta keduanya suatu bingkisan dari dalam syurga. Lalu kedua malaikat itu menyampaikan katanya: "Keluarlah, wahai jiwa yang telah mencapai keternteramannya, dengan ridha dan diridhai Allah. Keluarlah kepada Roh dan Raihan.Tuhan senang kepadamu, Tuhan tidak marah kepadamu."Maka keluarlah Roh itu, lebih harum dari kasturi."

"Kembalilah kepada Tuhanmu, dalam keadaan ridha dan diridhai." (ayat 28). Artinya: setelah payah engkau dalam perjuangan hidup di dunia yang fana, sekarang pulanglah engkau kembali kepada Tuhanmu, dalam perasaan sangat lega karena ridha; dan Tuhan pun ridha, karena telah menyaksikan sendiri kepatuhanmu kepada_nya dan tak pernah mengeluh.Maka masuklah ke dalam golongan hambahamba-Ku." (ayat 29). Di sana telah menunggu hamba-hamba-Ku yang lain, yang sama taraf perjuangan hidup mereka dengan kamu; bersama-sama di tempat yang tinggi dan mulia. Bersama para Nabi, para Rasul, para shadiqqin dan syuhadaa. " $W a$ hasuna ulaa-ika rafiiqa"; Itulah semuanya yang sebaik-baik teman."Dan masuklah ke dalam syurga-Ku." (ayat 30). Di situlah kamu berlepas menerima cucuran nikmat yang tiadakan putus-putus daripada Tuhan; Nikmat yang belum pernah mata melihatnya, belum pernah telinga mendengarnya, dan lebih daripada apa yang dapat 
dikhayalkan oleh hati manusia. Dan ada pula satu penafsiran yang lain dari yang lain; yaitu annafs diartikan dengan roh manusia, dan rabbiki diartikan tubuh tempat roh itu dahulunya bersarang. Maka diartikannya ayat ini: "Wahai Roh yang telah mencapai tenteram, kembalilah kamu kepada tubuhmu yang dahulu telah kamu tinggalkan ketika maut memanggil," sebagai pemberitahu bahwa di hari kiamat nyawa dikembalikan ke tubuhnya yang asli. Penafsiran ini didasarkan kepada qiraat (bacaan) Ibnu Abbas, Fii 'Abdii dan qiraat umum Fii "Ibaadil.

Begitu pula firman Allah Subhanahu wa Ta'ala,

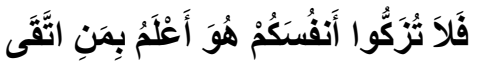

"Maka, janganlah kamu menganggap dirimu suci. Allah lebih mengetahui tentang siapa yang bertakwa." (Qs. an-Najm/53: 32).

Serta firman Allah Subhanahu wa Ta'ala,

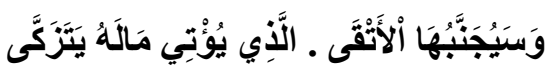

"Dan orang yang paling bertakwa akan dijauhkan dari api neraka, yaitu orang yang menginfakkan hartanya serta menyucikan dirinya." (Qs. al-Lail/92: 17-18).

Kedua ayat ini menjelaskan bahwa pembersihan jiwa pada hakikatnya adalah ketakwaan kepada Allah. Dan memang tujuannya adalah ketakwaan kepada Allah. Di sini perlu juga dipahami dengan baik sabda Rasulullah shallallahu 'alaihi wasallam berikut,

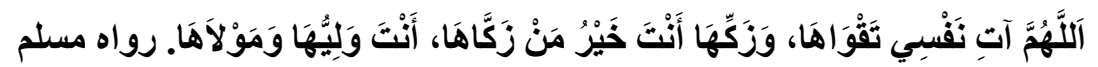

"Ya Allah! Anugerahkanlah ketakwaan pada jiwaku, bersihkanlah ia, Engkau adalah sebaik-baik yang membersihkan jiwa. Engkaulah Penguasa dan Pemiliknya." (HR. Muslim).13

Dengan qalbu serta jiwa yang bersih dan bertakwa, akan tercapailah maksud diciptakannya manusia. Yaitu hanya beribadah dan menyembah kepada Allah saja. Allah berfirman,

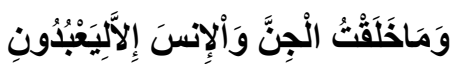

"Aku tidak menciptakan jin dan manusia kecuali hanya untuk beribadah kepada-Ku saja." (Qs. adz-Dzaariyaat/51: 56).

\section{Makna spiritual dalam Islam}

Manusia memang memiliki ruh dalam arti nyawa. Namun pada faktanya, dalam diri manusia tidak ada dua unsur pembentuk yang menarik manusia kepada dua kecenderungan yang berbeda, yakni unsur jasad menarik kearah pemenuhan 
kepentingan duniawi dan unsur jiwa/roh yang menarik kepada pemenuhan kepentingan ukhrowi (moral dan ritual). Kenyataannya, semua perbuatan manusia dipengaruhi oleh dorongan kebutuhan-kebutuhan fisik (al-hajatul 'udlwiyah) dan naluriah (al-ghoro'iz). Kebutuhan fisik contohnya adalah kebutuhan untuk makan, minum, buang hajat dan tidur; sedangkan kebutuhan naluri contohnya adalah naluri untuk melestarikan jenis manusia (ghorizatun nau'), naluri untuk mempertahankan diri (ghorizatul baqo'), dan kebutuhan untuk mensucikan dan mengagungkan dzat yang lebih agung dan sempurna (ghorizatut tadayyun).

Menurut Islam, kebutuhan-kebutuhan fisik dan naluriah tersebut merupakan sesuatu yang alami dan netral, tidak bisa dengan sendirinya dikatakan bahwa kebutuhan yang satu lebih tinggi derajatnya dari kebutuhan yang lain. Justru cara manusia dalam mengatur dan memuaskan kebutuhan-kebutuhan itulah yang dapat diberi predikat terpuji atau tercela. Dalam pandangan Islam, jika kebutuhankebutuhan tersebut dipenuhi dengan perbuatan yang dijalankan sesuai petunjuk Islam, maka ia akan menjadi perbuatan yang terpuji. Sebaliknya, jika kebutuhankebutuhan tersebut dipenuhi dengan perbuatan yang melanggar tuntunan Islam maka ia menjadi perbuatan yang tercela. Kebutuhan akan seks, misalnya, jika dipenuhi dengan berzina maka menjadi suatu hal yang tercela, namun jika dipenuhi dalam bingkai pernikahan yang sah maka akan menjadi bagian dari ibadah yang terpuji. Naluri alami untuk mensucikan dzat yang lebih agung yang mendorong aktivitas ritual keagamaan yang sering dianggap sebagai aktivitas ruhaniyah itu jika dijalankan tanpa petunjuk Islam maka akan menjadi bid'ah yang tercela, namun jika dijalankan berdasarkan petunjuk Al Qur'an dan As Sunnah maka akan menjadi ibadah yang terpuji, berpahala dan diridhoi oleh Allah.

Lantas apa yang mengarahkan manusia kepada aktivitas pemenuhan kebutuhan yang diridhoi oleh Allah? Inilah yang menjadi misteri bagi kebanyakan orang. Mereka merasakan kehadirannya, tapi tidak mampu mengidentifikasi hakekat dari sesuatu yang mendorongnya untuk taat kepada Allah itu. Sebagian orang menyangka bahwa faktor yang mendorong manusia untuk taat kepada Allah itu adalah roh atau jiwa yang bersemayam di dalam badannya. Sebab jiwa/roh merupakan kekuatan suci dan positif yang menarik manusia untuk mengorbit kepada kepentingan ukhrowi. Anggapan ini sepenuhnya merupakan khayalan yang tidak bisa dibuktikan. 
Sebenarnya, sesuatu yang mendorong manusia untuk cenderung melakukan perbuatan terpuji dalam memenuhi kebutuhan-kebutuhannya bukanlah unsur halus yang bersemayam dalam diri manusia. Dorongan itu sebenarnya berasal dari kesadaran yang ia miliki akan hubungannya dengan Allah Ta'ala (al idrok lishillatihi billah). Kesadaran bahwa Allah selalu mengawasi inilah yang membuat manusia taat kepadaNya. Ia kesadaran tersebut akan menguat tatkala mendengarkan nasehat yang sangat menyentuh, melihat fenomena yang menampakkan keagungan Allah, atau tatkala termotivasi oleh orang lain yang melaksanakan ibadah dengan lebih baik. Kesadaran itu pula yang melemah atau hilang tatkala manusia tergoda untuk melaksanakan maksiat atau meninggalkan suatu kewajiban. Kesadaran yang kadang menguat dan kadang pula melemah inilah sebenarnya yang mereka sebut dengan ruh. Disebut ruh karena secara rancu kesadaran ini dianggap sebagai salah satu unsur penyusun manusia, berupa jiwa yang bersemayam di dalam diri manusia. Padahal, keberadaan ruh yang berarti kesadaran itu jelas bukan merupakan unsur penyusun manusia melainkan hasil prestasi manusia dalam memahami, menyadari dan memunculkan kesadaran bahwa dirinya selalu diawasi dan dinilai oleh Allah.

Eksistensi ruh dalam diri seorang muslim menuntutnya untuk selalu mengendalikan seluruh perbuatan yang ia lakukan dengan hukum-hukum syara'. Maka selama ruh itu ada dalam benaknya, seorang muslim kemanapun dia pergiakan selalu berjalan di atas hukum syara' laksana kereta api yang selalu berjalan di atas relnya. Kehadiran ruh tersebut mendorong seorang muslim untuk melaksanakan sholat, haji, puasa dan aktivitas ritual lain sesuai dengan hukum syara'. Hadirnya ruh juga mendorong manusia untuk melaksanakan bisnis, jual-beli, hutang-piutang, bekerja, bergaul, berumah tangga, sampai menata pemerintahan menggunakan hukum syara'.

Atas dasar itu, ruh tidak hanya hadir di tempat-tempat sujud, tidak hanya hadir di sekitar Ka'bah, tidak hanya hadir di masjid-masjid, namun ia juga hadir di pasar-pasar, di kantor-kantor, bahkan di kamar kecil sekali pun. Aktivitas spiritual umat islam tidak hanya dimanifestasikan dalam sholat, puasa, haji dan dzikir, namun spiritualitas dan kedekatan dengan Allah juga teraktualisasikan dalam bisnis, pekerjaan, pergaulan, hukum, politik-pemerintahan bahkan juga terwujud dalam hubungan suami-istri. Umat islam sepenuhnya hidup dalam dimensi spiritual sekaligus menjalani kehidupan yang serba material. Inilah falsafah kehidupan dalam 
islam, yakni penyatuan antara materi dengan ruh. Yang demikian itu terjadi tatkala semua aktivitas manusia dijalankan dengan hukum-hukum syara' atas dasar kesadaran akan hubungan mereka dengan Allah.Dengan demikian, sebenarnya dalam Islam tidak ada dikotomi antara urusan dunia dengan urusan akhirat. Pengawasan dan penilaian Allah atas seluruh amal perbuatan manusia yang membawa konsekuensi pahala dan siksa merupakan benang merah yang menghubungkan antara dunia dan akhirat. Semuanya adalah amalan dunia, namun semuanya akan membawa dampak di akhirat. Dr. Abdul Qodir 'Audah menyatakan:

"hukum-hukum Islam dengan segala jenis dan macamnya diturunkan untuk kebahagiaan manusia di dunia dan di akhirat. Oleh karena itu, setiap aktivitas duniawi selalu memiliki aspek ukhrowi. Maka aktivitas ibadah, sosial kemasyarakatan, persanksian, perundang-undangan atau pun kenegaraan semuanya memiliki pengaruh yang dapat dirasakan di dunia ... akan tetapi, perbuatan yang memiliki pengaruh di dunia ini juga memiliki pengaruh lain di akhirat, yaitu pahala dan sanksi akhirat"

Inilah spiritualitas dalam islam. Ia adalah spiritualitas yang membumi, menyatu dengan dinamika kehidupan manusia dalam kesehariannya. Kerohanian dalam islam bukanlah dimensi yang berseberangan dengan kehidupan dunia. Bahkan, ruh yang kenyataannya adalah kesadaran akan hubungan seorang muslim dengan Allah ini harus dibawa ke mana pun seorang muslim itu pergi, dalam kondisi apapun, dan dalam menjalani aktivitas serta urusan apa pun. Inilah makna sejati dari dzikrullah (mengingat Allah), yakni sadar bahwa ia selalu diawasi oleh Allah dalam segenap gerak-geriknya sehingga mendorong seorang muslim untuk selalu hidup dengan syariat Islam tanpa lepas sedikit pun. Demikianlah cara orang-orang yang beriman untuk mentransendensikan seluruh aktivitas mereka di dunia dan "melayani" Allah dalam setiap urusan yang mereka kerjakan.

\section{Faktor yang Mempengaruhi Perkembangan Spiritual}

Spiritual adalah komponen penting dari seorang individu yang dimiliki dan sebuah aspek integral dari filosofi holistik. Perkambangan spiritual pasti mengalami keadaan yang tidak selalu baik seperti halnya fisik. Secara langsung maupun tidak langsung ada beberapa hal yang mempengaruhi perkembangan spiritual. Spiritualitas tidak selalu berkaitan dengan agama, tetapi spiritualitas adalah 
bagaimana seseorang memahami keberadaannya dan hubungannya dengan alam semesta. Orang-orang mengartikan spiritualitas dengan berbagai cara dan tujuan tersendiri. Setiap agama menyatakan bahwa manusia ada dibawah kuasa Tuhan. Namun, dari semua itu setiap manusia berusaha untuk mengkontrol spiritualitasnya. Inilah yang disebut dengan menjaga kesehatan spiritual. Hal terpenting yang mempengaruhi perkembangan spiritual dan sebaiknya kita jaga adalah nutrisi spiritual. Hal ini termasuk mendengarkan hal-hal positif dan pesan-pesan penuh kasih serta memenuhi kewajiban keagaman yang dianut. Selain itu juga dengan mengamati keindahan dan keajaiban dunia ini dapat memberikan nutrisi spiritual. Menilai keindahan alam dapat menjadi makanan bagi jiwa kita.Bahkan serangga yang terlihat buruk pun adalah sebuah keajaiban untuk diamati dan dinilai.

Zohar dan Marshall (2010) mengungkapkan ada beberapa faktor yang mempengaruhi kecerdasan spiritual yaitu:

a. Sel saraf otak

Otak menjadi jembatan antara kehidupan bathin dan lahiriah.Ia mampu menjalankan semua ini karena bersifat kompleks, luwes, adaptif dan mampu mengorganisasikan diri. Menurut penelitian yang dilakukan pada era 1990-an dengan menggunakan WEG (Magneto-Encephalo-Graphy) membuktikan bahwa osilasi sel saraf otak pada rentang $40 \mathrm{~Hz}$ merupakan basis bagi kecerdasan spiritual.

b. Titik Tuhan (God spot)

Ada bagian dalam otak, yaitu lobus temporal yang meningkat ketika pengalaman religious atau spiritual berlangsung yang disebut sebagai titik Tuhan atau God Spot. Titik Tuhan memainkan peran biologis yang menentukan dalam pengalaman spiritual. Namun demikian, titik Tuhan bukan merupakan syarat mutlak dalam kecerdasan spiritual. Perlu adanya integrasi antara seluruh bagian otak, seluruh aspek dari dan seluruh segi kehidupan.

\section{Mengukur Kecerdasan Spiritual}

Dalam tesis yang disusun oleh King (2008) ada empat komponen kecerdasan spiritual yang masing-masing mewakili pengukuran kecerdasan spiritual secara menyeluruh yaitu Critical Existential Thinking (CET), Personal Meaning Production (PMP), Transcendental Awareness (TA), dan Conscious State Expansion (CSE). 


\section{a. Critical Existential Thinking (CET)}

Komponen pertama dari kecerdasan spiritual melibatkan kemampuan untuk secara kritis merenungkan makna, tujuan, dan isu-isu eksistensial atau metafisik lainnya (misalnya realitas, alam, semesta, ruang, waktu, dan kematian). Berpikir kritis eksistensial dapat diterapkan untuk setiap masalah hidup, karena setiap objek atau kejadian dapat dilihat dalam kaitannya dengan eksistensi seseorang. Sementara beberapa mendefinisikannya sebagai upaya untuk memahami jawaban" (Koenig, 2000 dalam King 2009) atas pertanyaan-pertanyaan yang akhirnya tampak, secara lebih praktis dianggap sebagai pola perilaku yang berkaitan.

Pendapat lain mengatakan bahwa jika hanya mempertanyakan keberadaan saja tidak menunjukan penguasaan lengkap dari komponen ini. Selain harus mampu untuk merenungkan masalah eksistensial tersebut dengan berpikir kritistapi juga sampai pada kesimpulan murni atau filosofi pribadi tentang keberadaan, mengintegrasikan pengetahuan ilmiah dan pengalaman pribadi. Berpikir kritis, yang didefinisikan sebagai mengkonsep secara aktif dan kreatif, menerapkan, menganalisis, mensintesis, dan/atau mengevaluasi informasi yang dikumpulkan atau dihasilkan dari observasi, pengalaman, refleksi, penalaran, atau komunikasi (Scriven \& Paul, 1992, dalam King, 2009).

Pada instrumennya, King (2008) memformulasikan komponen ini pada unsur eksistensi, makna peristiwa, kehidupan setelah kematian, hubungan manusia dan alam semesta, dan mengenai Tuhan atau kekuatan yang lebih tinggi. Namun, penelitian yang dilakukan King tidak merujuk kepada agama tertentu atau non-agama sekalipun.

b. Personal Meaning Production (PMP)

Komponen inti kedua didefinisikan sebagai kemampuan untuk membangun makna pribadi dan tujuan dalam semua pengalaman fisik dan mental, termasuk kemampuan untuk membuat dan menguasai tujuan hidup. Nasel (2004) dalam King (2009) setuju bahwa kecerdasan spiritual melibatkan kontemplasi makna simbolis kenyataan dan pengalaman pribadi untuk menemukan tujuan dan makna dalam semua pengalaman hidup.

Sebagaimana dikatakan Frankl Dalam Zohar \& Marshall (2010) bahwa pencarian kita akan makna merupakan motivasi penting dalam hidup kita. 
Pencarian inilah yang menjadikan kita makhluk spiritual dan ketika kebutuhan makna ini tidak terpenuhi, maka hidup kita terasa dangkal dan hampa.

Makna pribadi didefinisikan sebagai memiliki tujuan di dalam hidup, memiliki arah, merasakan keteraturan, dan mengetahui alasan untuk keberadaannya (Reker, 1997 dalam King, 2009). Meddin (1998) dalam King (2009) mengidentifikasikan komponen kognitif makna pribadi sebagai kumpulan prinsip yang memungkinkan seseorang untuk masuk akal pada kehidupannya dari dalam dan lingkungan luar. Sebuah komponen kognitif juga disarankan oleh Wong (1989) dalam King (2009) yang mendefinisikan makna pribadi sebagai sistem kognitif yang dibangun oleh seseorang, yaitu mampu memberkati kehidupan dengan makna pribadi dan kepuasan.

Pada instrumennya, King (2008) memformulasikan komponen kepada unsurunsur kemampuan adaptasi dari makna dan tujuan hidup dan alasan hidup, makna kegagalan, mengambil keputusan sesuai dengan tujuan hidup, serta makna dan tujuan dari kejadian sehari-hari.

c. Transcendental Awareness (TA)

Komponen ketiga melibatkan kemampuan untuk melihat dimensi transenden diri, orang lain, dan dunia fisik (misalnya nonmaterial dan keterkaitan) dalam keadaan normal maupun dalam keadaan membangun area kesadaran. Wolman (2001) dalam King (2009) menjelaskan kesadaran transendental sebagai kemampuan untuk merasakan dimensi spiritual kehidupan, mencerminkan apa yang sebelumnya digambarkan sebagai merasakan kehadiran yang lebih nyata, yang lebih tersebar dan umum dari indera khusus kita.

Transendental selalu dikaitkan dengan ketuhanan, namun hasil riset Ecklund (2005) dalam Syahmuharnis \& Sidharta (2006), mahasiswa doktor tingkat akhir di Rice University, Houston, terhadap lebih dari 1.600 ilmuwan dari 21 universitas riset elit Amerika Serikat menyimpulkan, banyak orang Amerika yang tidak percaya dengan Tuhan, namun meyakini dirinya memiliki spiritual. Riset itu juga menemukan fakta bahwa spiritualisme kini menjadi hal yang semakin penting di Amerika, namun tetap memisahkan/membedakannya dengan agama.

Abraham Maslow, Hamel, Leclerc, dan Lefrancois (2003) dalam King (2009) telah menggambarkan proses tambahan aktualisasi transenden, yang mereka definisikan sebagai realisasi diri yang didirikan pada kesadaran 
pengalaman dari Pusat Spiritual (Spiritual Center), juga disebut sebagai Batin atau Inti. Csikszentmihalyi (1993) dalam King (2009) juga menyebutkan transendensi diri menggambarkan kesuksesan seseorang sebagai transcender yang bergerak melampaui batas-batas keterbatasan pribadi mereka dengan mengintegrasikan tujuan individu dengan yang lebih besar, seperti kesejahteraan keluarga, masyarakat, umat manusia, planet, atau kosmos. Demikian pula, Le dan Levenson (2005) dalam King (2009) menjelaskan transendensi-diri sebagai kemampuan untuk bergerak di luar kesadaran egosentris, dan melihat hal-hal dengan ukuran kebebasan yang cukup besar dari kondisi biologis dan sosial.

Pada instrumennya, King (2008) memformulasikan komponen ini kepada aspek non-fisik dan non-materi, mampu merasakan non-fisik dan non-materi, memahami hubungan antar manusia, mendefinisikan non-fisik (ruh), kualitas kepribadian/emosi, dan mampu memusatkan diri.

d. Conscious State Expansion (CSE)

Komponen terakhir dari model ini adalah kemampuan untuk memasukan area kesadaran spiritual (misalnya kesadaran murni, kesadaran murni, dan kesatuan) atas kebijakannya sendiri. Dari perspektif psikologis, perbedaan antara kesadaran transendental dan pengembangan area kesadaran ini didukung oleh Tart (1975) dalam King (2009) bahwa kesadaran transendental harus terjadi selama keadaan sadar normal, sedangkan pengembangan area kesadaran meliatkan kemampuan untuk mengatasi keadaan sadar dan area yang lebih tinggi atau spiritual. Sebuah pengembangan badan penelitian telah menunjukan perbedaan yang signifikan dalam fungsi otak antara semua tingkat dan area kesadaran, termasuk yang berhubungan degan pengalaman spiritual dan meditasi. Area tersebut adalah kesadaran kosmik, kesadaran murni, dan kesadaran unitive.

Kesadaran diri (self consciousness yang sering juga disebut dengan self awareness) adalah pembeda utama antara orang yang memiliki spiritualisme tinggi dengan yang tidak. Orang-orang yang memiliki kesadaran yang tinggi akan selalu berpikir beberapa kali dalam merespons setiap situasi, mengambil waktu sejenak untuk memahami apa yang tersembunyi maupun yang nyata sebelum menunjukan respons awal. Ia selalu bertindak penuh perhitungan, pertimbangan, dan hati-hati. (Syahmuharnis \& Sidharta, 2006). 
Dalam instrumennya, King (2008) memformulasikan komponen ini ke dalam unsur-unsur memasuki area kesadaran, mengontrol area kesadaran, bergerak dalam area kesadaran, melihat masalah dalam area kesadaran, dan mengembangkan teknik untuk area kesadaran.

Ciri-ciri kecerdasan spiritual

Berdasarkan teori Zohar dan Marshall (2001) dan Sinetar (2001), ciri-ciri kecerdasan spiritual adalah sebagai berikut:

1) Mempunyai kesadaran diri. Adanya tingkat kesadaran yang tinggi dan mendalam sehingga bisa menyadari antuasi yang datang dan menanggapinya.

2) Mempunyai visi. Ada pemahaman tentang tujuan hidupnya, mempunyai kualitas hidup yang diilhami oleh visi dan nilai-nilai.

3) Fleksibel. Mampu bersikap fleksibel, menyesuaikan diri secara spontan dan aktif untuk mencapai hasil yang baik, mempunyai pandangan yang pragmatis (sesuai kegunaan) dan efisien tentang realitas.

4) Berpandangan holistik. Melihat bahwa diri sendiri dan orang lain saling terkait dan bisa melihat keterkaitan antara berbagai hal. Dapat memandang kehidupan yang lebih besar sehingga mampu menghadapi dan memanfaatkan serta melampaui, kesengsaraan dan rasa sehat serta memandangnya sebagai suatu visi dan mencari makna dibaliknya.

5) Melakukan perubahan. Terbuka terhadap perbedaan, memiliki kemudahan untuk bekerja melawan konvensi dan status quo, menjadi orang yang bebas merdeka.

6) Sumber inspirasi. Mampu menjadi sumber inspirasi bagi orang lain, mempunyai gagasan-gagasan yang segar dan aneh.

7) Refleksi diri, mempunyai kecenderungan apakah yang mendasar dan pokok.

\section{Kecerdasan Spiritual}

Kecerdasan spiritual berhubungan dengan perlindungan dan pengembangan jiwa, yang dalam Kamus Bahasa Inggris Oxford didefinisikan sebagai "identitas moral dan emosional" serta intensitas dari "energi intelektual dan emosional". Kecerdasan spiritual (SQ), pertama kali dicetuskan oleh Danah Zohar dari Harvard University dan Ian Marshall dari Oxford University yang diperoleh berdasarkan 
penelitian ilmiah yang sangat komprehensif.Pada tahun 1977, seorang ahli syaraf, V.S. Ramachandran bersama dengan timnya dari California University, menemukan keberadaan God Spot dalam jaringan otak manusia dan ini adalah pusat spiritual (spiritual center) yang terletak di antara jaringan syaraf dan otak.

Kemudian dari spiritual center ini akan menghasilkan suara hati yang memiliki kemampuan lebih dalam menilai suatu kebenaran bila dibandingkan dengan pancaindra.Begitu hebatnya kekuatan dari suara hati yang berada di dalam God Spot, tetapi bagaimana bentuk dan jenisnya itu, belum ada satu orang penulis barat yang dapat mengidentifikasi suara hati tersebut.

Dilihat dari sejarahnya,antara EQ dan SQ memiliki jalan yang bertolak belakang, di mana pendukung aliran spiritual mencoba untuk menghalangi realitas ilmu.Walaupun keduanya berbeda, namun sebenarnya antara EQ dan SQ mempunyai kemampuan yang sama pentingnya dan saling mengisi antara satu dengan yang lainnya, yang kemudian terangkum ke dalam ESQ (Emotional and Spiritual Quotient), yaitu tingkat pemikiran baru yang dapat mengatasi permasalahan dalam hal pengembangan emosi dan spiritual berdasarkan prinsip.Adanya penggabungan ini dapat membentuk pribadi yang optimis, memiliki kepercayaan diri yang tinggi, berkreativitas, memiliki ketahanan mental, berintegrasi dan sebagainya yang kemudian dapat memberikan kesuksesan dalam kehidupan.

Kecerdasan spiritual berkaitan dengan masalah makna, nilai, dan tujuan hidup manusia. Dalam kondisi yang sangat buruk dan tidak diharapkan, kecerdasan spiritual mampu menuntun manusia untuk menemukan makna dan juga dapat menuntun manusia dalam meraih cita-citanya. Kecerdasan spiritual melampaui kemampuan untuk cerdas berpikir,merasa, bertindak dan berperilaku dalam konteks situasional atau kerangka kerja yang diberikan. Kecerdasan spiritual memungkinkan manusia untuk bijaksana dalam merefleksikan situasi untuk menemukan dirinya yang lebih bermakna sehingga mampu mengubah sesuatu menjadi lebih berharga (Mengel, 2005).

Zohar dan Marshal (2007) mengatakankecerdasan spiritual diartikan sebagai kecerdasan yang bertumpu pada bagian dalam diri yang berhubungan dengan kearifan di luar ego atau jiwa kesadaran. Sebagai kecerdasan yang senantiasa dipergunakan bukan hanya untuk mengetahui nilai-nilai yang ada, melainkan juga untuk secara kreatif menemukan nilai-nilai baru dalam kehidupan. Bila 
spiritualquotient (SQ) telah berkembang dengan baik, maka gambaran atau ciri-ciri orang yang memiliki kecerdasan spiritual (SQ) tinggi.

Menurut Zohar dan Marshall (2007), indikator kecerdasan spiritual (SQ) tinggi yaitu:

1) Kemampuan bersikap fleksibel (adaptif secara spontan dan aktif).

2) Tingkat kesadaran tinggi.

3) Kemampuan mengadaptasi dan memanfaatkan penderitaan.

4) Kemampuan menghadapi dan melampaui rasa sakit.

5) Kualitas hidup yang diilhami oleh visi dan misi.

6) Keengganan untuk menyebabkan kerugian yang tidak perlu.

7) Kecenderungan untuk melihat keterkaitan antara berbagai hal (berpendangan holisitik).

8) Kecenderungan nyata untuk bertanya "mengapa atau bagaimana mencari jawaban dasar.

9) Pemimpin yang penuh pengabdian dan bertanggung jawab.

\section{METODE PENELITIAN DAN PEMBAHASAN}

\section{Kerja adalah keniscayaan}

Kerja dalah sebuah aktifitas, yang menggunakan daya yang dianugerahkan Allah Swt, manusia secara garis besar, di anugreahi emapat daya pokok, pertama daya fisik yang menghasilkan fisik dan ketrampilan, kedua daya pikir, yang mendorong pemiliknya berpikir dan menghasilkan ilmu pengetahuan, ketiga daya kalbu yang menjadikan manusia mampu berkahyal, mengekpersikan keindahan, beriman, merasa serta berhubungan dengan Allah swt, sang pencipta dan empat daya hidup yang menghasilkan semangat juang, kemampuan menghadapi tantangan dan menanggulangi kesulitan, kerja adalah keniscayaan, akan tetapi perlu di ingat bahwa kerja atau amal yang di tuntut-Nya bukan asal kerja tetapi kerja yang dapat menghantarkan pelakunya untuk mendapatkan hasil yang sempurna atau atau amal soleh, shalih berarti yang sesuai dengan standarnya bermanfaat lagi memenuhi syarat syarat dan nilai nilainya,

Perintah Al quran kepada umat manusia agar beramal saleh serta pujian terhadap mereka yang aktif melakukannya demikian juga penghargaan kepada waktu bukanlah satu hal yang perlu dibuktikan 


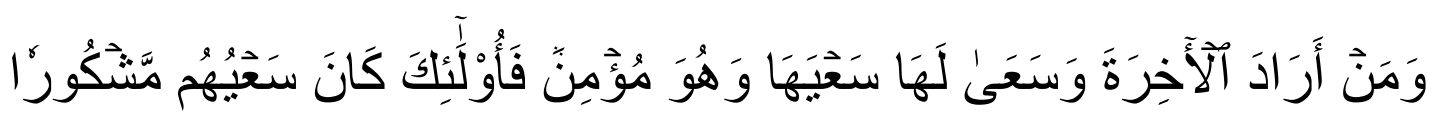

19. Dan barangsiapa yang menghendaki kehidupan akhirat dan berusaha ke arah itu dengan sungguh-sungguh sedang ia adalah mukmin, maka mereka itu adalah orangorang yang usahanya dibalasi dengan baik

Yang usaha mereka disyukuri yakni yang terpuji adalah yang visinya jauh ke depan mencapai akhirat, percaya kepada Allah swtdan keniscayaannya akhirat serta berusaha secara bersungguh sungguh.

Kata سعي sa'a pada mulanya berarti berjalan dengan cepat, lalu berkembang sehingga di gunakan dalam arti usaha sungguh sungguh, dengan demikian ayat ini menggaris bawahi perlunya kesungguhan dalam berusaha guna meraih apa yang dikehendaki dan di cita citakan. Kecerdasan spiritual ini adalah kecerdasan yang mengangkat fungsi jiwa sebagai perangkat internal diri yang memiliki kemampuan dan kepekaan dalam melihat makna yang ada di balik kenyataan apa adanya ini. Kecerdasan ini bukan kecerdasan agama dalam versi yang dibatasi oleh kepentingan-pengertian manusia dan sudah menjadi terkapling-kapling sedemikian rupa. Kecerdasan spiritual lebih berurusan dengan pencerahan jiwa. Orang yang berSQ tinggi mampu memaknai penderitaan hidup dengan memberi makna positif pada setiap peristiwa, masalah, bahkan penderitaan yang dialaminya. Dengan memberi makna yang positif itu, ia mampu membangkitkan jiwanya dan melakukan perbuatan dan tindakan yang positif.

Untuk mengetahui motivasi kerja dalam Islam, kita perlu memahami terlebih dahulu fungsi dan kedudukan bekerja. Mencari nafkah dalam Islam adalah sebuah kewajiban. Islam adalah agama fitrah, yang sesuai dengan kebutuhan manusia, diantaranya kebutuhan fisik. Dan, salah satu cara memenuhi kebutuhan fisik itu ialah dengan bekerja.

Motivasi kerja dalam Islam itu adalah untuk mencari nafkah yang merupakan bagian dari ibadah. Motivasi kerja dalam Islam bukanlah untuk mengejar hidup hedonis, bukan juga untuk status, apa lagi untuk mengejar kekayaan dengan segala cara. Tapi untuk beribadah.Bekerja untuk mencari nafkah adalah hal yang istimewa dalam pandangan Islam. 


\section{Motivasi Kerja Dalam Islam}

Cobalah simak beberapa kutipan hadist dibawah ini. Anda bisa melihat bagaimana istimewanya bekerja mencari nafkah menurut sabda Nabi saw.

Sesungguhnya Allah suka kepada hamba yang berkarya dan terampil (professional atau ahli). Barangsiapa bersusah-payah mencari nafkah untuk keluarganya maka dia serupa dengan seorang mujahid di jalan Allah Azza wajalla. (HR. Ahmad)

Luar biasa, dikatakan dalam hadits diatas bahwa mencari nafkah adalah seperti mujahid, artinya nilainya sangat besar. Allah suka kepada hambanya yang mau berusah payah mencari nafkah. Saya kira, ini lebih dari cukup sebagai motivasi kerja kita sebagai muslim. Bahkan, kita pun berpeluang mendapatkan ampunan dari Allah.

Barangsiapa pada malam hari merasakan kelelahan dari upaya ketrampilan kedua tangannya pada siang hari maka pada malam itu ia diampuni oleh Allah. (HR. Ahmad)

\section{Hukumnya Wajib}

Mencari rezeki yang halal dalam agama Islam hukumnya wajib.Inimenandakan bagaimana penting mencari rezeki yang halal. Dengan demikian, motivasi kerja dalam Islam, bukan hanya memenuhi nafkah semata tetapi sebagai kewajiban beribadah kepada Allah setelah ibadah fardlu lainnya.

Mencari rezeki yang halal adalah wajib sesudah menunaikan yang fardhu (seperti shalat, puasa, dll). (HR. Ath-Thabrani dan Al-Baihaqi)

Perlu diperhatikan dalam hadist di atas, ada kata sesudah. Artinya hukumnya wajib sesudah ibadah lain yang fardhu. Jangan sampai karena merasa sudah bekerja, tidak perlu ibadah-ibadah lainnya. Meski kita bekerja, kita tetap wajib melakukan ibadah fardhu seperti shalat, puasa, ibadah haji, zakat, jihad, dan dakwah. Jangan sampai kita terlena dengan bekerja tetapi lupa dengan kewajiban lainnya.

\section{Motivasi Kerja Sebagai Ibadah}

Jika motivasi kerja kita sebagai ibadah, tentu yang namanya ibadah ada aturannya. Memang berbeda dengan ibadah ritual atau ibadah mahdhah, sebab bekerja sebagai ibadah ghair mahdhah. Artinya, dalam kaidah ushul Fiqh, kita memiliki kebebasan yang luas untuk bekerja selama tidak bertentangan dengan ajaran Islam. Namun demikian, Islam mengatur batasan-batasan, meletakkan 
prinsip-prinsip dan menetapkan nilai-nilai yang harus dijaga oleh seorang muslim, agar kemudian aktifitas bekerjanya benar-benar dipandang oleh Allah sebagai kegiatan ibadah yang memberi keuntungan berlipat di dunia dan di akhirat. Berikut ini adalah batasan-batasan tersebut:

Pertama, pekerjaan yang dijalani harus halal dan baik. Allah berfirman,

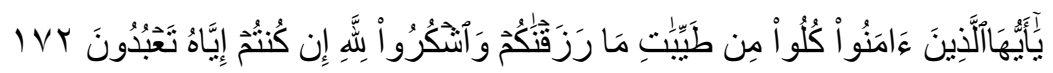

"Hai orang-orang yang beriman, makanlah di antara rezki yang baik-baik yang Kami berikan kepadamu dan bersyukurlah kepada Allah, jika benar-benar kepada-Nya kamu menyembah." (QS. Al Baqarah [2]: 172)

Setiap muslim diperintahkan untuk makan yang halal-halal saja serta hanya memberi dari hasil usahanya yang halal, agar pekerjaan itu mendatangkan kemaslahatan dan bukan justru menimbulkan kerusakan. Itu semua tidak dapat diwujudkan, kecuali jika pekerjaan yang dilakukannya termasuk kategori pekerjaan yang dihalalkan oleh Islam. Maka tidak boleh bagi seorang muslim bekerja dalam bidang-bidang yang dianggap oleh Islam sebagai kemaksiatan dan akan menimbulkan kerusakan. Diantara bentuk pekerjaan yang diharamkan oleh Islam adalah membuat patung, memproduksi khamr dan jenis barang yang memamukkan lainnya, berjudi atau bekerja dalam pekerjaan yang mengan-dung unsur judi, riba, suap-menyuap, sihir, ternak babi, mencuri, merampok, menipu dan memanipulasi dan begitu pula seluruh pekerjaan yang termasuk membantu perbuatan haram seperti menjual anggur kepada produsen arak, menjual senjata kepada orang-orang yang memerangi kaum muslimin, bekerja di tempat-tempat maksiat yang melalaikan dan merusak moral manusia dan lain sebagainya.

Kedua, bekerja dengan profesional dan penuh tanggungjawab. Islam tidak memerintahkan umatnya untuk sekedar bekerja, akan tetapi mendorong umatnya agar senantiasa bekerja dengan baik dan bertanggungjawab. Nabi shallallahu 'alaihi wa sallam bersabda,

"Sesungguhnya Allah mencintai seorang diantara ka-lian yang jika bekerja, maka ia bekerja dengan baik." (HR Baihaqi, dinilai shahih oleh Al Albani dalam "Silsilah As Shahihah")

Beliau juga bersabda, "Sesungguhnya Allah mewajib-kan perbuatan ihsan atas segala sesuatu.” (HR Muslim) 
Yang dimaksud dengan profesional dalam bekerja adalah, merasa memiliki tanggungjawab atas pekerjaan tersebut, memperhatikan dengan baik urusannya dan berhati-hati untuk tidak melakukan kesalahan.

Ketiga, ikhlas dalam bekerja, yaitu meniatkan aktifitas bekerjanya tersebut untuk mencari ridho Allah dan beribadah kepada-Nya.Nabi shallallahu 'alaihi wa sallam bersabda, "Sesungguhnya amal-amal perbuatan itu tergantung niat.Dan setiap orang akan mendapatkan balasan sesuai dengan apa yang diniatkannya." (HR Bukhari Muslim)

Niat sangat penting dalam bekerja. Jika kita ingin pekerjaan kita dinilai ibadah, maka niat ibadah itu harus hadir dalam sanubari kita. Segala lelah dan setiap tetesan keringat karena bekerja akan dipandang oleh Allah sebagai ketundukan dan amal shaleh disebabkan karena niat. Untuk itulah, jangan sampai kita melupakan niat tersebut saat kita bekerja, sehingga kita kehilangan pahala ibadah yang sangat besar dari pekerjaan yang kita jalani itu.

Keempat, tidak melalaikan kewajiban kepada Allah. Bekerja juga akan bernilai ibadah jika pekerjaan apa pun yang kita jalani tidak sampai melalaikan dan melupakan kita dari kewajiban-kewajiban kepada Allah. Sibuk bekerja tidak boleh sampai membuat kita meninggalkan kewajiban. Shalat misalnya. Ia adalah kewajiban yang harus dilaksanakan oleh setiap muslim. Maka, jangan sampai kesibukan bekerja mencari karunia Allah mengakibatkan ia meninggalkan shalat walau pun hanya satu kali. Begitu pula dengan kewajiban yang lainnya, seperti zakat, puasa, haji, bersilaturahmi dan ibadah-ibadah wajib lainnya.

Itulah beberapa prinsip dan etika penting yang harus dijaga oleh siapa saja yang tengah bekerja untuk mencukup diri dan keluarga yang berada dalam tanggungannya. Bekerja adalah tindakan mulia. Keuntungan dunia dapat diraih dengannya. Namun bagi seorang muslim, hendaknya bekerja menjadi memiliki keuntungan ganda, keuntungan di dunia dengan terkumpulnya pundi-pundi kekayaan, dan di akhirat dengan pahala melimpah dan kenikmatan surga karena nilai ibadah yang dikandungnya. Allah SWT menjadikan semua yang ada di bumi sebagai lapangan untuk mencari rezeki atau kehidupan. Oleh karena itu, bertebaranlah di muka bumi ini untuk mencari anugerah dari Allah SWT. Al-Qur'an menganjurkan manusia agar bersikap disiplin dan menggunakan waktu secara efektif dan efisien. Apabila seseorang ingin mengalami kesuksesan dalam kehidupannya, salah satu modal utama adalah memiliki etos kerja yang tinggi. Dalam risalah yang 
mengandung pedoman hidup yang lengkap dan lurus terdapat pula etos kerja, berupa pedoman dan tuntunan dalam bekerja supaya karyanya sukses dan berkah. Etos kerja yang datang dari Allah Pencipta dan Penguasa alam raya inilah yang paling tepat dan yang hak, karena tiada lagi keterampilan dan pengaturan dari makhluk manapun yang mampu menandinginya.[1] Makna bekerja bagi seorang muslim adalah suatu upaya yang sungguh-sungguh, dengan mengerahkan seluruh aset, fikir, dan dzikirnya untuk mengaktualisasikan atau menampakkan arti dirinya sebagai hamba Allah yang harus menundukkan dunia dan menempatkan dirinya sebagai bagian dari masyarakat yang terbaik (khoiro ummah) atau dengan kata lain dapat juga dikatakan bahwa hanya dengan bekerja manusia itu memanusiakan dirinya.

\section{Etos Kerja Seorang Muslim}

Jika tujuan bekerja begitu agung. Untuk mendapatkan ridha Allah SWT, maka etos kerja seorang Muslim haruslah tinggi. Sebab motivasi kerja seorang Muslim bukan hanya harta dan jabatan, tetapi pahala dari Allah. Tidak sepantasnya seorang Muslim memiliki etos kerja yang lemah. Coba perhatikan diatas, ada katakata "susah payah" dan "kelelahan" yang menandakan etos kerja yang tinggi, suka bekerja keras, dan jauh dari sifat malas.

Jadi, tidak ada kata malas atau tidak serius bagi seorang Muslim dalam bekerja. Motivasi kerja dalam Islam bukan semata mencari uang semata, tetapi serupa dengan seorang mujahid, diampuni dosanya oleh Allah SWT, dan tentu saja ini adalah sebuah kewajiban seorang hamba kepada Allah SWT.

1. Profesional dan Ahli

Dalam hadits diatas juga disebutkan kata profesional dan ahli. Jika motivasi kerja Anda sebagai ibadah, maka Anda akan melakukannya dengan sebaik mungkin. Anda akan terus meningkatkan pengetahuan dan keterampilan Anda dalam bekerja. Anda terus belajar dan berlatih agar semakin hari menjadi semakin ahli dalam bekerja. Kemauan Anda untuk belajardan meningkatkan kemampuan bisa dijadikan ukuran apakah motivasi kerja Anda untuk ibadah atau bukan.

2. Adil Dalam Bekerja

Salah satu bentuk profesional itu adalah 'adil, yaitu menempatkan sesuatu pada tempatnya. Jika waktunya bekerja, Anda bekerja. Jika waktunya istirahat 
atau shalat, Anda bisa shalat dan istirahat. Jika tidak, maka bisa termasuk melakukan hal yang dzalim, tidak menempatkan sesuatu pada tempatnya. 'Adil juga berarti, Anda bekerja sesuatu tugas, wewenang, dan tanggung jawab yang Anda miliki.

Kecerdasan spiritual ini adalah kecerdasan yang mengangkat fungsi jiwa sebagai perangkat internal diri yang memiliki kemampuan dan kepekaan dalam melihat makna yang ada di balik kenyataan apa adanya ini. Kecerdasan ini bukan kecerdasan agama dalam versi yang dibatasi oleh kepentingan-pengertian manusia dan sudah menjadi terkapling-kapling sedemikian rupa.Kecerdasan spiritual lebih berurusan dengan pencerahan jiwa.Orang yang ber-SQ tinggi mampu memaknai penderitaan hidup dengan memberi makna positif pada setiap peristiwa, masalah, bahkan penderitaan yang dialaminya. Dengan memberi makna yang positif itu, ia mampu membangkitkan jiwanya dan melakukan perbuatan dan tindakan yang positif.

\section{Delapan Ciri-ciri Orang Yang Memiliki Kecerdasan Spiritual yang Berkembang}

1. Fleksibel

Orang yang memiliki kecerdasan spiritual tinggi di tandai dengan sikap hidupnya yang fleksibel atau luwes. Orang ini dapat membawa diri dan mudah menyesuaikan diri dengan berbagai situasi yang dihadapi, tidak kaku atau memaksakan kehendak. Ibarat air, ia dapat menyesuaikan diri dengan bentuk wadahnya. Demikian pula orang ini mudah mengalah.Dengan demikian dapat menerima berbagai keadaan.

2. Kemampuan Refleksi Tinggi

Orang yang memiliki kecerdasan spiritual tinggi, memiliki kemampuan refleksi yang tinggi. Dia cenderung bertanya mengapa atau bagaimana seandainya sebagai kelanjutan apa dan bagaimana. Orang ini juga suka bertanya atau merenungkan hal-hal yang fundamental : dari mana asalnya manausia ini dan kemana arah hidup manausia; darimana alam semesta ini; mengapa ada takdir dan nasib dan sebagainya. Mereka juga memiliki kemampuan yang tinggi pula dalam menganalisis persoalan rumit dan persoalan metafisika. 


\section{Kesadaran Diri dan Lingkungan Tinggi}

Kesadaran tinggi berarti telah mengenal dirinya dengan sebaik-baiknya.Dia telah mampu mengendalikan dirinya, misalnya mengendalikan emosi dan dorongan-dorongan lainnya. Dengan mengenal dirinya, maka dia juga mengenal orang lain, mampu membaca mnaksud dan keinginan orang lain. Kesadaran lingkiungan tinggi mendakup kepedulian terhadap sesama, persoalan hidup yang dihadapi bersama dan juga perduli terhadap lngkungan alam, seperti kecintaan terhadap flora dan fauna.

\section{Kemampuann Kontemplasi Tinggi}

Kemampuan komtemplasi tinggi adalah kemampuan mendapat aspirasi dari berbagai hal yakni kemampuan menyampaikan nilai dan kakna kepada orang lain (memberi inspirasi), mengamati berbagai hal untuk menarik hikmahnya atau mendapat inspirasi, memiliki kreatifitas tinggi dan kemampuan inovasi yang berasal dari inspirasi yang didapatnya.

\section{Berpikir Secara Hilostik}

Berpikir secara holistik adalah berfikir secara menyeluruh, mengaitkan berbagai hal yang berbeda-beda. Berpikir secara sistem, tidak terkotak-kotak atau tersegmentasi. Dengan berfikir secara holistik, maka akan terlihat hubungan antara satu hal dengan hal lainnya. Dia juga menghargai perbedaan-perbedaan dan mampu bersinergi. Dan berfikir bahwa segala sesuatu di alam ini adalah satu kesatuan sistem yang besar, dimana komponen-komponennya saling mendukung.

6. Berani Menghadapi dan Memanfaatkan Penderitaan

Segala kesulitan hidup merupakan tempaan atau ujian untuk meningkatkan kesadaran diri seseorang.Untuk belajar melepaskan kelekatan duniawi, maka seseorang misalnya harus mengalami kehilangan barang, kehilasngan orang yang dicintai, kehilangan pekerjaan, jabatan dan sebagainya.Hendaknya kita mengambil hikmah yang positif dari semua kejadian yang kita alami. Bagaimanapun mula-mula kita merasa sakit hati atas kehi8langan apa yang kita miliki. Namun dari situ kita juga belajar pasrah atau menerima kejadian yang telah kita alami.

\section{Berani Melawan Arus dan Tradisi}

Ada kebijakan yang mengatakan, sebaiknya kita hidup mengalir seperti air ikuti sajalah kemana arus membawa kita. Namun disini kita ditantang untuk melawan arus jika dibutuhkan. Para Nabi pada umumnya adalah orang yang 
melawan arus dan merombak tradisi masyarakatnya.Meskipun untuk itu harus menghadapi perlawanan dari orang-orang yang ingin mempertahankan tradisi itu. Tradisi yang buruk saat ini sedang terjadi di tengah bangsa Indonesia, yaitu tradisi korupsi. Betapa banyak pegawai yang korupsi, mulai dari tingkat atas hingga bawah. Tidak hanya di lingkungan kantor pemerintah saja, juga dilingkungan perusahaan swasta. Korupsi jelas menyebabkan ambruknya tatanan masyarakat kita. Maka beranikah melawan arus hidup di tengah masyarakat yang korup? Kita ditantang untuk menjadi seperti bunga teratai, meskipun hidup di atas lumpur tetap bisa menampilkan keindahannya, tanpa tercemar oleh lumpur tempat hidupnya.

\section{Sedikit Mungkin Menimbulkan Kerusakan}

Pada saat ini kita sering mendengar berbagai bencana alam dan musibah yang terjadi diberbagai penjuru dunia. Banyak bencana alam yang terjadi karena ulah manusia, misalnya: penggunaan bahan bakar yang berlebihan sehingga menimbulkan efek rumah kaca sehingga bumi semakin panas dan es kutub mencair, naiknya tingkat permukaan air laut dan menenggelamkan daratan yang rendah. Penebahan hutan yang tidak terkendali dapat menyebabkan banjir lokal dan perubahan iklim dunia.

Seseorang yang mempunyai tingkat kecerdasan spiritual (SQ) tinggi cenderung menjadi seorang pemimpin yang penuh pengabdian, yaitu seseorang yang bertanggungjawab untuk membawakan visi dan nilai yang lebih kepada orang lain dan memberikan petunjuk penggunaannya. Dengan kata lain seseorang yang memberi inspirasi kepada orang lain.

\section{Implementasi Kecerdasan Spiritual di Tempat Kerja}

Seperti apakah peran SQ di tempat kerja? Karyawan dengan SQ yang tinggi biasanya akan lebih cepat mengalami pemulihan dari suatu penyakit, baik secara fisik maupun mental. Ia lebih mudah bangkit dari suatu kejatuhan atau penderitaan, lebih tahan menghadapi stres, lebih mudah melihat peluang karena memiliki sikap mental positif, serta lebih ceria, bahagia dan merasa puas dalam menjalani kehidupan.Berbeda dengan karyawan yang memiliki SQ rendah. Pada orang dengan SQ rendah, keberhasilan dalam hal karier, pekerjaan, penghasilan, status dan masih banyak lagi hal-hal yang bersifat materi ternyata tidak selalu mampu membuatnya 
bahagia. Persaingan dan perbedaan kepentingan yang berlangsung begitu ketat sering kali membuat manusia kehilangan arah dan identitas.

Perubahan teknologi yang pesat menghasilkan tekanan yang begitu besar, yang terkadang membutakan manusia dengan kecerdasan spiritual rendah dalam menjalani visi dan misi hidupnya, membuat ia lupa melakukan refleksi diri dan lupa menjalankan perannya sebagai bagian dari komunitas. Kesibukan kerja dan keberhasilan yang dicapai tidak diamalkannya untuk penciptaan arti dan nilai bagi lingkungan.

Bagaimana membentuk kecerdasan spiritual yang tinggi di tempat kerja? Manusia memiliki pikiran dan roh, ingin mencari arti dan tujuan, berhubungan dengan orang lain dan menjadi bagian dari komunitas. Oleh karenanya,organisasi perlu membentuk budaya spiritualitas di lingkungan kerja. Organisasi yang bersifat spiritual membantu karyawannya untuk mengembangkan dan mencapai potensi penuh dari dirinya (aktualisasi diri). Robbins \& Judge dalam bukunya yang berjudul Organizational Behavior menyebutkan budaya spiritualitas yang perlu dibentuk adalah:

\section{Strong Sense of Purpose}

Meskipun pencapaian keuntungan itu penting, tetapi hal itu tidak menjadi nilai utama dari suatu organisasi dengan budaya spiritual. Karyawan membutuhkan adanya tujuan perusahaan yang lebih bernilai, yang biasanya dinyatakan dalam bentuk visi dan misi organisasi.

\section{Trust and Respect}

Organisasi dengan budaya spiritual senantiasa memastikan terciptanya kondisi saling percaya, adanya keterbukaan dan kejujuran. Salah satunya dalam bentuk manajer dan karyawan tidak takut untuk melakukan dan mengakui kesalahan.

\section{Humanistic Work Practices}

Jam kerja yang fleksibel, penghargaan berdasarkan kerja tim, mempersempit perbedaan status dan imbal jasa, adanya jaminan terhadap hak-hak individu pekerja, kemampuan karyawan, dan keamanan kerja merupakan bentuk-bentuk praktik manajemen sumber daya manusia yang bersifat spiritual.

\section{Toleration of Employee Expression}

Organisasi dengan budaya spiritual memiliki toleransi yang tinggi terhadap bentuk-bentuk ekspresi emosi karyawan. Humor, spontanitas, keceriaan di tempat 
kerja tidak dibatasi.Saat ini sudah cukup banyak perusahaan yang menerapkan budaya spiritualitas di tempat kerja.

Bahkan ada perusahaan yang mendorong dan mengizinkan setiap karyawan untuk menyediakan satu persen dari waktu kerjanya untuk melakukan pekerjaan sukarela bagi pengembangan komunitas, seperti: membagikan makanan kepada para tunawisma, kerja bakti membersihkan taman umum,mendirikan perpustakaan atau rumah baca untuk anak-anak jalanan,dan memberi bantuan bagi korban bencana alam.

Southwest Airlines adalah contoh sukses sebuah organisasi spiritual. Pembentukan budaya spiritual di Southwest Airlines telah membuat perusahaan itu menjadi salah satu perusahaan penerbangan dengan turn over terendah, secara konsisten memiliki biaya tenaga kerja terendah per jarak penerbangan, secara tetap mencatat waktu tiba yang lebih cepat dan tingkat komplain yang lebih rendah dibandingkan pesaingnya, dan terbukti merupakan perusahaan penerbangan yang paling konsisten dalam hal keuntungan di industri penerbangan Amerika Serikat. Dengan terbentuknya budaya spiritualitas di tempat kerja, diharapkan akan terbentuk karyawan yang happy, tahu dan mampu memenuhi tujuan hidup. Karyawan yang demikian umumnya memiliki hidup yang seimbang antara kerja dan pribadi, antara tugas dan pelayanan.

Pada umumnya, mereka juga memiliki kinerja yang lebih tinggi. Hasil penelitian yang dilakukan sebuah perusahaan konsultan besar, penerapan lingkungan kerja yang spiritual meningkatkan produktivitas dan menurunkan turn over. Studi lainnya menunjukkan, karyawan yang kecerdasan spiritualnya tinggi dan didukung lingkungan kerja yang juga spiritual, secara positif menjadi lebih kreatif, memiliki kepuasan kerja yang tinggi, mampu bekerja dengan baik secara tim, dan memiliki komitmen yang tinggi terhadap organisasi.

\section{SIMPULAN}

Spiritualisme di dalam agama adalah kepercayaan, atau praktek-praktek yang berdasarkan kepercayaan bahwa jiwa-jiwa yang berangkat (saat meninggal) tetap bisa mengadakan hubungan dengan jasad. Hubungan ini umumnya dilaksanakan melalui seorang medium yang masih hidup. Ada keterlibatan emosional yang kuat, 
baik pada penolakan maupun penerimaan terhadap spiritualisme ini yang membuat sulitnya suatu uraian imparsial dipakai untuk membuktikannya.

Spiritualitas berkaitan erat dengan dimensi lain dan dapat dicapai jika terjadi keseimbangan dengan dimensi lain (fisiologis, psikologis, sosiologis, cultural). Spiritual sangat berpengaruh terhadap koping yang dimiliki individu. Semakin tinggi tingkat spiritualindividu, maka koping yang dimiliki oleh individu tersebut juga akan semakin meningkat. Sehingga mampu meningkatkan respon adaptif terhadap berbagai perubahan yang terjadi pada diri individu tersebut. Kompetensi spiritual merupakan dua sisi mata uang yang tidak bisa dipisahkan dengan kompetensi sosial yaitu kompetensi dalam memberikan kenyamanan kepada orang lain. Dengan kompetensi spiritual dan sosial dapat membangun SDM pegawai yang produktif, beriman, kontributif, kreatif dan inovatif. Dengan demikian bila kecerdasan spiritualdilaksanakan di tempat kerja maka pelayanan publik yang efisien, efektif, berkeadilan, transparan, akuntabel, dan bermoralitas tinggi dapat diwujudkan sesuai dengan harapan.

Untuk penerapan kompetensi spiritual diperlukan komitmen dan konsistensi untuk melakukan perbaikan diri terus menerus. Untuk itu membuat agenda dan evaluasi diri dilakukan setiap hari. Hati harus senantiasa dibersihkan dari berbagai kotoran penyakit hati setiap saat dengan bertobat dan melakukan perbaikan. Islam memiliki kecenderungan sebagai civil religion yang dihayati dan diamalkan sebagai reaksi terhadap perubahan masyarakat yang sangat cepat akibat kemajuan ilmu pengetahuan.

\section{DAFTAR PUSTAKA}

Al quran dan terjemah depag

An-Nawawi, (1998) Shahih Muslim Syarh an-Nawawi, tahqiq: Khalil Ma'mun Syiha, Dar al-Ma'rifah, cet. III, 1417 H/1996 M, XVII/43.

Ary Ginanjar Sebastian, (2003). Rahasia Sukses Membangkitkan "ESQ Power" sebuah Inner Journey Melalui Al-Ihsan. Penerbit Arga, Jakarta.

Danah Zohar dan Ian Marshall, (2002). SQ Memanfaatkan Kecerdasan Spiritual dalam Berfikir Integralistik dan Holistik Untuk Memaknai Kehidupan, Mizan, Bandung.

Daniel Goleman, (2000). Kecerdasan Emosionaal : Mengapa EI Lebih Penting daripada IQ, Gramedia Pustaka Utama, Jakarta.

Departemen Agama RI, (2010) Mushaf Al-Qur'an dan terjemahannya 
Harjani Hefni, (2008). The 7 Islamic Daily Habits, Percetakan IKADI, Jakarta.

Kurniasih. (2010). Mendidik SQ Anak Menurut Nabi Muhammad SAW. Yogyakarta: Galangpress.

Lembaga Administrasi Negara, (2009). "Kecerdasan Spiritual” Modul Pilot Project Pendidikan dan Pelatihan Prajabatan Golongan III (Student's Book).

Malini, H. (2009). Hubungan Kecerdasan Spiritual Dengan Perilaku Caring Perawat di RS

DR.M.DJAMIL PADANG.Artikel Ilmiah. Program Studi Ilmu Keperawatan Fakultas Kedokteran Universitas Andalas.

Qomariah, N. (2012). Hubungan Kecerdasan Spiritual dengan Perilaku Caring Perawat pada

Praktek Keperawatan di Ruang Rawat Inap RSUP Haji Adam Malik Medan.Skripsi. Fakultas Keperawatan Universitas Sumatera Utara. Medan.

Ruslan,H.M, (2008) Menyingkap rahasia spiritualitas Ibnu 'Arabi ( Cet.I; Makassar:Al-Zikra, 2008),h.16

Rosalina, W. L. (2008). Pengaruh Kecerdasan Emosional Perawat Terhadap Perilaku Melayani Konsumen Dan Kinerja Perawat Rumah Sakit Umum Daerah Kabupaten Indramayu dalam

http://www.isjd.pdii.lipi.go.id/admin/jurnal/2308195215.pdf, diakses pada tanggal 15 Februari 2014

Rudyanto.(2010). Hubungan antara Kecerdasan Emosi dan Kecerdasan Spiritual dengan Perilaku

Suryawati, P.N. (2010). 100 Pertanyaan Penting Perawatan Gigi Anak.Jakarta : Dian Rakyat.

Suwardi (2008). Hubungan antara kecerdasan emosi dengan kemampuan komunikasi terapeutik perawat Di Rumah Sakit Umum Pandan Arang Boyolali dalam http://etd.eprints.ums.ac.id. Skripsi tidak dipublikasikan.Universitas Muhammadiyah Surakarta, diakses pada tanggal 14 september 2016.

Qadir Abdulallah, (1985) Al Islam baina Jahli Abna'ihi wa 'Ajzi 'Ulama'ihi (tt: al Itihad al Islami al 'Alami lil Munadhomat ath thulabiyah, 1985)Tafsir.cahcepu.com/alfajr/al-fajr-27-30. 